\title{
Turning the Mirror on Ourselves Research on Teaching in Postsecondary Education
}

\begin{abstract}
James J. F. Forest
James J. F. Forestis researchassociate for the Boston College Center for Internotional Higher Education, and policy and research analyst for the Mossochusetts Higher Education Coordinating Council.
\end{abstract}

$\mathrm{U}$ niversity and college teaching and the assessment and reward of teaching are among the most important topics in higher education worldwide, and their importance is increasing. Research on college teaching has generated widely circulated journals such as Change, College Teaching, and the newly established Teaching in Higher Education, while some of the most internationally prominent journals in the field of higher education have devoted whole issues to the subject. Over the past five years, approximately one out of every four articles in Higher Education, the most widely circulated international journal in the field, has focused on the topic of college teaching. Professional researchers associations in Australia, Canada, the United States, and throughout Europe have commissioned papers and research studies assessing the work of academics. Thus, the body of literature on teaching in postsecondary education is rapidly expanding.

Policymakers and researchers are giving greater attention to this subiect, for related but different reason the former, in response to increasing public demands for accountability in higher education and the latter, out of concern for improving student learning. Thus, there are two significant trends of research under the general rubric of college teaching. One is concerned with the general effectiveness of faculty members' use of allocated resources. This performance- or accountability-drivenresearch contributes to the decision-making process of many institutions, as well as of state higher education governing bodies. Another significant area of research centers on the effectiveness of classroom interaction between teacher and student. This essay briefly explores both of these trends, and argues for more attention to the latter, and not the former.

\section{Policymakers, Faculty Productivity, and Accountability}

One of the contributing causes to this rise in attention toward college teaching has been a trend of unprecedented increases in tuition and fees, compelling students and their parents (and increasingly, government officials) to take a closer look at how that money is being spent. As well, although higher education is arguably a public and social good, increasingly a college degree is perceived as being a private good - hence the growing public reluctance to foot the bill for rising costs in public higher education. The demands for accountability have generated the type of research that responds to such 'faculty productivity' issues as teaching workload, classroom contact hours, and average class size. Faculty productivity reports have been produced by the National Center for Education Statistics and the American Association of University Professors, as well as by a variety of state higher education governing boards, including those of New York, Florida, Washington, Pennsylvania and the California State University system, to name just a few.

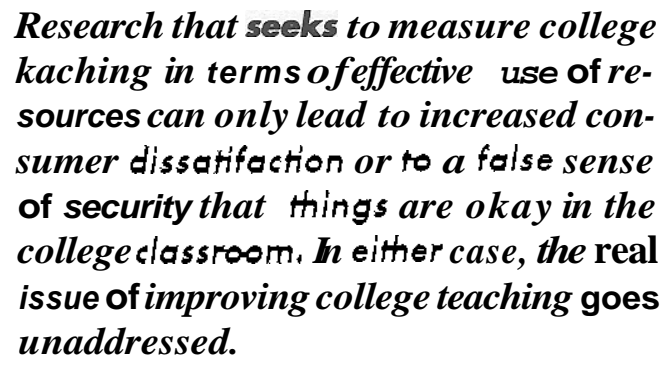

However, this form of research on college teaching does not produce any real indication of the quality of teaching that occurs in the classroom. This form ofresearch asks the wrong questions, and largely prevents us from getting at the much more important issue: bow to improve college teaching. Research on improving college teaching (and its companion, student learning) is far more elusive and complex than the simple "credit hours generated" and "courses taught per semester" or-my personal favorite whipping post-"student/faculty ratio," which are the most common products of current accountability-drivenresearch on the work of academics. Research of this nature, which seeks to measure college teaching in terms of productive use of resources, can lead in only two directions: 1)institutions that are shown to have "poor" quantitative results in such research are easy targets for public criticism, at a time where the public is already wary of rising tuition costs; or 2) institutions showing "good" quantitative results by these sorts of measures can be easily lulled into a false sense that things are okay in the college classroom. In either case, the real issue of improving college teaching goes unaddressed. 


\section{Research on Improving College Teachingand Student Learning} The literature on improving college teaching and student learning has seen a great deal of growth throughout the first half of this decade. Research of this nature largely encompasses three major areas of focus: student learning issues, including cognitive strategies and the effects of curriculum; college instruction, including preferred teaching strategies and criteria for evaluating effective teaching; and the roles and responsibilities of the higher education institution, including teaching policies and administrative involvement in efforts to improve teaching.

Recent examples include a number of "handbooks," which generally incorporate theoretical perspectives of student learning with advice for practitioners from expertsin their field. These books contain chapters on topics ranging from the assessment of teaching effectiveness, to communication and diversity issues, to incorporating technology into a science curriculum. Some of the most recent and notable contributions to this growing body of literature include: McKeachie, Teaching Tips; Prichard and Sawyer, Handbook of College Teaching: Theory and Applications; Angelo and Cross, Classroom Assessment Techniques; and Halpern et al., Changing College Classrooms: New Teaching and Learning Strategies for an Increasingly Compkx World.

In addition to multitopic handbooks, a number of smallerbooks, such as Ernest Boyer's groundbreaking Scholarship Reconsidered:Priorities of the Professoriate and Alexander Astin, What Matters in Colkge? have had a significant impact on discussions surrounding the improvement of college teaching. Professional journals for student affairs personnel associations (such as the National Association of Student Personnel Administrators and the American College Personnel Association, in the United States) are also increasingly contributing to the discussion. This area of research on college teaching is far more valuable than are studies concerned with academics' effective use of resources. However, some contributing factors to the growth of research on the improvement of college teaching are not unrelated to the research on measuring faculty productivity.

College practitioners have over the past six years been asked to do more with less-that is, teach more classes, teach larger classes, and with fewer instructional support resources. An overwhelming majority of college teachers currently in the profession have never had any formal training on how students learn or how to develop effective teaching strategies. Rather, the academic profession has for centuries upheld the myth that a $\mathrm{Ph} . \mathrm{D}$. meant a license to teach, one that could not be revoked or subject to review for renewal. A trend has developed where academics are now being forced to take the responsibility for learning what it takes to be a good college teacher, and if institutions have employed poor college teachers, then (the public is saying) the institution has a duty to help that professional developthe necessary skills and abilitiesto become a good college teacher. These new themes of research, which incorporate student cognitive development, facultystudent communication, and a wide range of other aspects of classroom interaction are steps in the right direction.

Research of this nature transcends geographic boundaries - the nature of interaction between teacher and learner is just as important and complex in Asia as in Europe or Latin America. College teaching is an important exercises that can and should be affected by proper planning and careful execution. Each class in a student's career becomes a building block for his or her future learning and ability to cope with their broader environment. The number of scholars studying college teaching is growing, both in the United States and abroad. It seemsreasonable, then, to suggest a more global approach to current and future research and discussions on improving college teaching. There are many dimensions under the general rubric of university and college teaching, including preparation, assessment, and reward. From an international perspective, within each of these dimensions reside a number of cultural and socialinfluences, such as language, religion, and history. However, despite the many complex differences across geographic locales, it is quite possible to observe the many commonalities in the thinking and approaches toward college teaching that pervade higher education systems worldwide, and from these commonalities derive the insights needed to address the challenges of today's higher education environment. Selected References on Teaching in Higher Education

Thomas A. Angelo and Patricia K Cross, Classroom Assessment Techniques: A Handbok for College Teacbers (San Francisco, Calif.:Jossey-Bass, 1993).

Ernest Boyer, Scholarship Reconsidered: Priorities of the Professoriate (Princeton, N.J.: The Carnegie. Foundation for the Advancement of Teaching, 1990).

Diane Halpern, et.al., Changing College Classrooms: New Teaching and Leaning Strategies for an Increasingly Complex World (San Franasco, Calif.: Jossey-Bass, 1994).

Wilbert J. McKeachie, Teaching Tips: Strategies, Research and Theory for College and University Teachers (Lexington, Mass.: D.C. Heath and Co., 1994).

Keith W. Prichard and R. McLaren Sawyer, eds, Handbook of College Teacbing: Theory and Applications (Westport, Conn.: Greenwood Press, 1994). 